\title{
Negotiating Biological and Cultural Features of Music: Towards the Field of Biomusicology
}

\author{
Uğur Aslan \\ Center for Advanced Studies in Music, Istanbul Technical University, Istanbul, Turke. \\ Email: uguraslango@hotmail.com
}

Received February 5, 2017; Revised April 11, 2017; Accepted April 15, 2017; Published May 7, 2017.

\begin{abstract}
The aim of this article is to observe the domain of Biomusicology, sub-branches, its methods, theories and approaches. Thus, this article also tries to understand two different sides of Biomusicology, which are biological and cultural components of music, in general the difference between Humanities/Social Sciences and Natural Sciences. Biomusicology, as an interdisciplinary field, is derived from many different disciplines such as Biology, Ethnomusicology, Musicology, Cognitive Science, and Psychology. By the different approaches, the field of Biomusicology investigates the origins of music, musical universals and neurological human music-making process in all biological and cultural dimensions. In this way, Biomusicology attempts to negotiate biological and cultural approaches of music and find a solution for cultural/biological dichotomy in music studies (Cross 2001: 514). By doing this, Biomusicology also tries to fill the gap between Humanities/Social Sciences and Natural Sciences as an interdisciplinary field, which coins new paradigm for a future research.
\end{abstract}

Keywords: Biomusicology, Biology, Ethnomusicology, Evolutionary Musicology, Neuromusicology, Comparative Musicology

\section{Introduction}

By the end of the $20^{\text {th }}$ century, the rise of interdisciplinary studies influenced the theories and methodologies in science. Consequently, new fields and sub-disciplines occurred due to interdisciplinarity. For the field of Biomusicology, interdisciplinary studies are not the only component. Changing paradigm, interest in cognitive science, 'instinct' questions about the music making process and the origins of music affected the field of Biomusicology and formed it.

One of the most remarkable features of Biomusicology is that biological and cultural approaches are combined in this field. By doing this, Biomusicology attempts to melt the social sciences and natural sciences in the same spot. Because of this situation, Biomusicology creates biological/cultural dichotomy due to differences between social and natural sciences. However, in many ways, Biomusicologists try to deal with both ways in their studies. This discussion is clear under the topic of musical universals and comparative musicology. The aim of this paper is to investigate this issue in general in the field of Biomusicology.

Although Biomusicology showed up by the end of the $20^{\text {th }}$ century, the interest for the origins of music and musical universals, which are also the main interests of Biomusicology, have been there even before Biomusicology due to we are always interested in these kind of instinct questions. The first part of this article includes the historical background of Biomusicology in this context. In the second part of the article, general information about the field of Biomusicology is (c) AesthetixMS 2016. This Open Access article is published under a Creative Commons Attribution Non-Commercial 4.0 International License (http://creativecommons.org/licenses/by-nc/4.o/), which permits non-commercial re-use, distribution, and reproduction in any medium, provided the original work is properly cited. For citation use the DOI. For commercial re-use, please contact editor@rupkatha.com. 
mentioned. Thirdly, the sub-branches of Biomusicology, which are evolutionary musicology, neuromusicology and comparative musicology, are described in terms of their subject and the main interests.

\section{Historical Background of Biomusicology}

What is the origin of music? This instinct question was there even before the discipline of Ethnomusicology. In the $18^{\text {th }}$ century, Philosophical and intellectual processing included the theories for the origin of music as a part of history via the Enlightenment process in Europe. The well-known work from this period of time is Jean-Jacques Rousseau's ([1781] 1998) Essay on the Origin of Languages and Writings Related to Music. Rousseau, in his work, aesthetically traces the relationship between the origin of language and the aesthetic of Eurogenetic Art music. Although it is one of the earliest works related to the origin of music, we might consider it as a milestone in the way of Biomusicology.

The same interest on this question continued in the $19^{\text {th }}$ century as well. Despite the relationship between language and music was one of the issues in the origins of music in the $19^{\text {th }}$ century, Darwin's evolution theory came up to investigate the origins of music and it is discussed among scholars such as Herbert Spencer, who is a social Darwinist scholar, in this period. When Adler (1885) (As cited in Mugglestone and Adler 1981) divides the study of music into two disciplines which are called Historical Musicology and Systematic Musicology, he also included comparative musicology, which tries to find the musical universals, as a subdivision of Systematic Musicology. It was another turning point for investigating musical universals in the context of origin of music. Early comparative musicologists such as Lomax, Sachs, Hornbostel, and Kolinski were interested in common musical features of world of music and in this sense they had the same interest as Biomusicologists have. However, their studies provide a great source for the field of Biomusicology.

Another important issue for scholars in the $19^{\text {th }}$ century is the contradictive description of Primitive Music that derived from the Darwin's evolutionary theory. The general idea about Primitive Music stands in the music of tribes which is the closest music to the "first" musical practices of human beings. In this sense, scholars were considering Eurogenetic music to be more superior than Primitive Music. Even though this approach is put away in recent studies, it formed the studies in the $19^{\text {th }}$ century. For instance, Wallaschek (1893) in his book titled Primitive Music, talks about the origins of music and he believes that rhythm is the essence of music in all "Primitive music". However, according to Nettl (2015:37) "The nineteenth-century scholars such as Spencer, Wagner, Bücher, Stumpf, Darvin, were interested in why music came about”.

In the beginning of $2 \mathrm{O}^{\text {th }}$ century,scholars also were working on distinguishing music from nonmusic via comparative methodologies. However, scholars were still interested in finding out the origin of music. For instance, psychologist Carl Stumpf ([1911] 2012), shows that interest in his book, The Origins of Music. This is an important study for the field of Biomusicology because it provided useful materials for the cognitive theory of musical evolution which is also a field of interest of Biomusicology.

Rising interdisciplinary studies after 1980's and using the gains from specializations via the collaboration with scholars from other disciplines, created a suitable environment for the field of Biomusicology in the 1990's. Scholars from different disciplines have been holding the same research questions for the origins of music and the common musical features which can be found 
in every musical system. As it is discussed in this paper, there are diverse methodological and theoretical approaches in the field of Biomusicology due to finding answers for these research questions.

\section{The Field of Biomusicology}

Biomusicology, is an interdisciplinary field which includes theories and methodologies from disciplines like Biology, Musicology, Ethnomusicology, Psychology, and Cognitive Sciences. When the first workshop in Biomusicology was held in Fiesole, Italy, in May 1997, papers raised many questions which have been asked by comparative musicologists and scholars who were interested in the origins of music. By this attempt, they also coined new approaches for the future research. Few questions are crucial for those who don't know much about Biomusicology: what differs Biomusicology from other interdisciplinary fields? What is the interest of Biomusicology? Scholars from which disciplines study in Biomusicology? And what is the contribution of Biomusicology to science?

First of all, according to Graham (2015: 108) "Biomusicology is the study of the interface between body, mind and music”. At the same time, because of the nature of biology, it doesn't only count the humans but also it takes on account the animals as well. In this context, Fitch (2015: 1) indicates that "Bio-musicology' is the biological study of musicality in all its forms". Generally, Biomusicology deals with comparative methodologies. Fitch (2015: 1-2) explains the comparative nature of Biomusicology in two ways. "First that it takes as its domain all of human music-making (not privileging any one culture, or 'art music' created by professionals) and second that it seeks insight into the biology of human musicality, wherever possible, by looking at related traits in other animals".

Another important point about the rise of Biomusicology is cognitive sciences which showed up in the late twentieth century. Cross (2001) indicates that Biomusicology is related to sociobiological explanations of behavior, the rise of "evolutionary psychology", and cognitive science. At the same time, Cross (2001: 513) mentions that "avoidance of engagement with culture and biology was always going to be problematic". Because of the specialization in a field, scholars were not able to understand each other. This gap was so clear, maybe is still there, in between humanities and natural sciences. However, Biomusicology seems like an attempt to cross borders and engage with different disciplines. Cross (2001: 514) explains this situation of Biomusicology by saying "there are few ways to observe cultural/biological dimensions of music. Abjuring the cultural dimension, considering only cultural dynamics that make music, and reconciliation between the cultural and the biologically material". Biomusicology applies to latter one by respecting both humanities/social sciences (such as Ethnomusicology, Musicology) and natural science (such as Biology, Cognitive Science).

Although Cross (2001) mentions that Biomusicology reconciles between cultural and biological material, some scholars tend to distinguish these dimensions from each other and interpret these issues from this point of view. For instance, Peretz (2006: 1) discusses that music is only viewed as a cultural invention and its biological context is rarely studied in the literature. However, one can come across this discussion in the literature while talking about the universals in music. This separation is highly involved in the field of Biomusicology. So we can ask this question: is music a biological fact or cultural determined? Or is it both? Fitch (2006: 206) applies this question by combining both approaches in terms of musical ability: 
The study of the biology of human musical abilities will be valuable not only for its own intrinsic interest, but for the light it may shed on the biology and evolution of human language. For example, most humans are musically "enculturated", possessing a basic set of music perception skills that are nearly universal (e.g., Koelsch, Gunter, Friederici, \& Schro" ger, 2000; Schellenberg \& Trehub, 2003; Trainor, McDonald, \& Alain, 2002), but finer differences in perceptual abilities exist and may have a biological basis (e.g., Drayna, Manichaikul, de Lange, Snieder, \& Spector, 2001; Peretz, Ayotte, Zatorre, Mehler, \& Ahad, 2002) (as cited in Fitch 2006: 206).

In another words, Biomusicology agrees on some key points in general. Fitch (2015: 1) explains these four principles of Biomusicology as it is mentioned below the text:

These involve adopting: (i) a multicomponent approach which recognizes that musicality is built upon a suite of interconnected capacities, of which none is primary; (ii) a pluralistic Tinbergian perspective that addresses and places equal weight on questions of mechanism, ontogeny, phylogeny and function; (iii) a comparative approach, which seeks and investigates animal homologues or analogues of specific components of musicality, wherever they can be found; and (iv) an ecologically motivated perspective, which recognizes the need to study widespread musical behaviours across a range of human cultures (and not focus solely on Western art music or skilled musicians).

\section{The Sub-Branches of Biomusicology}

The field of Biomusicology focuses on two varied research areas by biological and musicological theories. The first one is related to ontological questions of music which are mainly based on the origins of music. The second one is more about epistemological questions for music practices, musical coordination as biological aspect in universal music practices, universals of music, and musical capacity. However, we can see both ontological and epistemological approaches in the field of Biomusicology, which is coined in the beginning of 1990's.

The term of "Biomusicology" was coined by Wallin in 1991. The field of Biomusicology consists of three main branches and sub-branches. These main branches are "Evolutionary Musicology", "Neuromusicology", and "Comparative Musicology".

Evolutionary Musicology deals with the evolutionary origins of music, both in terms of a comparative approach to vocal communication in animals and in terms of an evolutionary psychological approach to the emergence of music in the hominid line. Neuromusicology deals with the nature and evolution of the neural and cognitive mechanisms involved in musical production and perception, as well as with ontogenetic development of musical capacity and musical behavior from the fetal stage through to old age. Comparative Musicology deals with the diverse functional roles and uses of music in all human cultures, including the contexts and contents of musical rituals, the advantages and costs of music making, and the comparative features of musical systems, forms, and performance styles throughout the world (Brown, Merker and Wallin 2001:5).

Although Brown, Merker, and Wallin (1991) divide the Biomusicology into three branches, these branches are connected to each other and they can apply to each other. For instance, "universals in music" is one of the issues in the Evolutionary Musicology, but at the same time Comparative Musicology observes the universals in music in the biological sense. In the following chapters, three main branches of Biomusicology will be explained by their innate approaches and theories. 
6 | Negotiating Biological and Cultural Features of Music: Towards the Field of Biomusicology

\subsection{Evolutionary Musicology}

Evolutionary Musicology is one of the most remarkable branches of Biomusicology in terms of ontological features of music. Brown, Merker and Wallin's (2001) Origins of Music can be considered as one of the main sources of Evolutionary Musicology due to providing a holistic approach and other contributions from many disciplines by different theories. Methods for the evolutionary musicology are analysis of animal songs, physical anthropology and musical archeology, music-language comparative analysis, human brain imaging, and comparative musicology (Brown, Merker and Wallin 2001).

Origins of Music shows the general issues of Evolutionary Musicology. The first issue is vocal communication in animals, which deals with the comparative methodology of animal songs and human songs. The second issue is related to music-language and human evolution, which tries to find similarities between language and music. Universals in music, which asks how to make a connection between common musical features around the world and the origins of music, forms the general issues of Evolutionary Musicology.

The first approach, which holds the comparative methodology of animal songs and human songs, comprises of basic and common elements of animal and human songs. Morgan (2014:138) indicates that "Due to its origins in the natural world and its many similarities with facets of human music and melody, bird song has long held interest for composers, musicologists, and music aesthetes. Many cultures around the world are affected by bird song such as Kaluli people of Papua New Guinea, Avian music in Afghanistan, Wawanji people of Tanzania and Sierra Leone". Nevertheless, scholars investigated the tie of bird song and origins of music.

Comparative studies have revealed that music engages the same neuroaffective mechanisms of intended audience in birds and humans. However, this idea is undermined by the fact that song or even just vocal mimicry has arisen in distinctly different parts of the animal kingdom (birds, humans, dolphins, and whales) (Morgan 2014: 140).

Despite the similar vocal mimicry between animals and humans has been getting the attention by scholars, biomusicologists attempt to make connection between animal songs and human songs in the basis of biology, thus, they try to find out the origins of music in this sense. However, some problems and critics arise from this issue. Although scholars attempt to find out the biological basis in the origin of music, the difference between enculturation process and evolutionary or biological structures, creates discussion related to the origin of music. Another important issue is that biomusicologists generally focus on the functional meaning of music (Wallin 1991: 8-9).

While human vocalizations clearly build upon an acoustic and emotional foundation shared with other primates and mammals, vocal learning has evolved independently in our species since our divergence with chimpanzees. The convergent evolution of vocal learning in other species offers a powerful window into psychological and neural constraints influencing the evolution of complex signaling systems (including both song and speech), while ape drumming presents a fascinating potential homology with human instrumental music (Fitch 2006: 173).

Another approach for the origin of music tries to find connection between music and language. For instance, Atherton (2007: 15) "identifies the vocalizations of pitch and rhythmic material as rhythm-speak and suggests that language play, the speaking and singing of nonsense syllables, and vocal mimicry constitute behaviors that stem from the origins of music itself, and that these activities form the basis of creative exploration and improvisation". At the same time, "music and 
language research seem to share interests in both evolutionary origins and cognitive underpinnings of their respective objects of inquiry" (Ravignani and Gingras 2013:2).

Ravignani and Gingras (2013: 3) also describe the important questions about the relationship between language and music from three different approaches. These questions also shape the discussions about the dichotomy between language and music in the field of Biomusicology.

1. The evolutionary approach. What is the relationship between the origins of language and music? Can findings in one discipline inform the other? Which experiments are crucial to reject or accept hypotheses of common origins? Are the common origin (a musilanguage split into language and music) and branching (music originated by scission from language or vice-versa) hypotheses tenable at all?

2. The cognitive approach. To what extent do language and music processing overlap in the brain and mind? How can experimental studies inform us about shared neural resources? In particular, do structural similarities in language and music map to shared processing mechanisms?

3. The methodological approach. Current research on language evolution makes, among others, a broad use of agent-based modeling, iterated learning experiments and comparative research in non-human animals. How are similar techniques used to investigate the evolution of music? What kind of models and computer simulations could be "imported" from language to music research (and vice versa) successfully and meaningfully? (Ravignani and Gingras 2013:3)

Secora (2014:430) indicates that music in evolutionary theory has been seen as "a skill or inclination that may be used in social realms to mark an individual apart from other conspecifics or to brand an individual in terms of group identity". Music has occurred by evolution by natural selection but for some scholars music is one of the prime example of an evolutionary adaptation (Secora 2014: 431). Evolutionary perspective of music is held via scholars in terms of Darwinians concepts. From this point of view, they attempts to find the function of music. According to Huron (1999), music might be evolved for seven reason. These sevens reasons are mate selection, social cohesion, group effort, auditory development, conflict reduction, safe time passing, and transgenerational communication.

\subsection{Neuromusicology}

The branch of Neuromusicology in Biomusicology is mainly related to the Cognitive Science, Music Cognition and Neurological Studies. Although these studies are highly empirical, they may provide a new understanding in the reception of music and cognitive capacities for musical function. For instance Brown (2003: 16) indicates that "Neurological Studies have documented numerous interesting brain lesions that lead to specific losses of musical function while sparing other cognitive capacities, and conversely, brain lesions that destroy much cognitive functioning but that preserve music".

However, besides providing a new understanding for our brain, Neuromusicology can also work in a sense of Applied Biomusicology. For instance, Neuromusicology is described as the "scientific study of the effects of music on the brain" by the AccessScience editors (2016) and they also mention that "neuromusicology will prove valuable in attempts to treat deficits in motor function, behavior (including autism), cognition (including attention and memory), speech, and pain management".

The first understanding of neuromusicology is about reception of music, music cognition and cognitive capacities for musical function, as it is mentioned before. For instance, Levitin (2013) talks about being in an absolute pitch and how neuromusicology can help us to understand this 
issue. According to Levitin, "the reason why some children acquire this ability and others do not may be simply be because they were taught it and made an effort to learn it" (Levitin 2003:18). Levitin (2003) also indicates that there is no connection between being absolute pitch and genes. However, "they may encode proteins that contribute to component abilities that are required for the development of AP, specifically such subskills as auditory memory, auditory attention, conditional associative learning, categorical perception, and perhaps even a predisposition toward absolute versus relative features of certain perceptual stimuli” (Levitin 2003: 18).

Neuromusicology includes music and language studies by applying cognitive science as well. In this context, Neuromusicology can both provide a new insight for the origins of music and new theories for music making process in a biological term. For instance, Leongomez (2014: IV) speaks on the relationship between music and language in terms of cognitive science:

Our brain, physiology and psychology make us capable of producing and listening to music since early infancy; therefore, our biology and behaviour are carrying some of the clues that need to be revealed to understand what music is "for". Furthermore, music and language have a deep relationship, particularly in terms of cognitive processing, that can provide clues about the origins of music.

Not only about music and language but also for the musicing process Neuromusicology can be applied. Wittmann and Pöppel suggest that "a neurobiological determined tempo of all the participants can easily lead to the coordination of the individual clocks of the musicians, thus leading to synchronization of musical performance" (1999-2000: 19)" (As cited in Clayton, Sager, and Will 2005:32). In this sense, entrainment theory also takes place in music cognition and correlatively in Neuromusicology.

\subsection{Comparative Musicology}

Despite the main issue of comparative musicology is investigating musical universals in human cultures, it is not only to observe human cultures, but it applies to biological standpoint of animals as well. In this context, comparative methodology is applied in order to find out the similarities between human cultures and animals in a biological sense. For instance, Murdock, categorizes the musical universals, which meet on a common ground of "animal" level of human culture, into three branches. "(a) corresponding to primary, genetically coded (instinctive) impulsions, (b) corresponding to acquired habits, rooted in fundamental bio-psychological demands, and (c) corresponding to cultural habits with only very thin links to the conditions of the secondary level" (as cited in Wallin 1991:8).

"The idea of musical universals does nothing if not place all of humankind on equal ground, acting as biological safeguard against ethnocentric notions of musical superiority" (Brown, Merker and Wallin 2001:13). From this point of view, Biomusicologists try to put biological evidences in order to demonstrate the musical universals in human culture. Nevertheless, to attempt to find musical universals is not an innovation, which emerges with the branch of comparative musicology. Early comparative musicologists, who were studying before the existence of ethnomusicology, were eager to find out the musical universals by applying musical sound. Contrary to early comparative musicologists, Biomusicologists also count on musical behavior, meaning, motions and musical gestures. In this context, they would like put musical universals in both musicological and biological way (Savage and Brown 2013: 174).

For the branch of comparative musicology, which is placed in Biomusicology, is connected with the comparative musicology, which is named before ethnomusicology. However, early 
comparative ethnomusicologists such as Lomax, Stumpf, Kolinski are effective in the branch of comparative musicology. Therefore, ethnomusicologists stay far from the use the name of "comparative musicology". For instance, Bruno Nettl (2001:471) says that we will never know that there are musical universals or not. But at the same time he suggests ethnomusicologists to engage with this question due to importance of it.

However, other discussions involve in the branch of Biomusicology. For instance, describing music is an important issue in comparative musicology. The question of "what is music?" is one of the crucial components, which shapes the study, in comparative musicology.

\section{Conclusion}

Biomusicology, as an interdisciplinary field, is derived from many different disciplines such as Biology, Ethnomusicology, Musicology, Cognitive Science, and Psychology. In this context, Biomusicology may be seen as innovative field due to evoking instinct questions again. This pervasive point of Biomusicology is operated both culturally and biologically. Thus, the field of Biomusicology has a strong influence in the literature and it provides negotiation between humanities/social science and natural science.

Although combining cultural and biological components is always going to be problematic, Biomusicology invokes a new understanding as an intermediary between ethno-musicologists and biologists. In this context, Biomusicologists intervene interdisciplinary field, which is bridging two totally different disciplines. Thus, the field of Biomusicology integrally applies to interdisciplinary theories in order to find persuasive answers.

Although these kind of sincere attempts help us come closer to the 'purer' truth, investigating musical universals may be problematic because of cultural/biological dichotomy. For instance, Ethnomusicologist Bruno Nettl mentions that we will never know that there are musical universals or not. In this sense, he clearly speaks from the point of Ethnomusicology. However, Biomusicologists attempt to find the musical universals in terms of biological and musicological sense. For this kind of interdisciplinary studies, scholars should understand each other and for this reason, interdisciplinary seminars, congress and symposiums, where scholars from different disciplines gather and engage, are really important for the future research, not only in Biomusicology but also at any kind of interdisciplinary field.

\section{Acknowledgements}

I would like to thank Robert Reigle for his contributions and suggestions which shaped this paper during class at MIAM.

\section{References}

AccessScience Editors. (2016). Neuromusicology. In AccessScience. McGraw-Hill Education. https://doi.org/10.1036/1097-8542.BRo224161. Accessed Date: 07.01.2017

Mugglestone, E. Adler, G. (1981). "Guido Adler's "The Scope, Method, and Aim of Musicology" (1885): An English Translation with an Historico-Analytical Commentary”. Yearbook for Traditional Music. Vol.13. pp. 1-21. 
Atherton, M. (2007). “Rhythm-Speak: Mnmonic, Language Play or Song?”. The inaugural International Conference on Music Communication Science. Pp. 15-18.

Brown, S. (2003). "Biomusicology, and three biological paradoxes about music". Bulletin of Psychology and the Arts. 4(1):15-17.

Brown, S., Merker, B., and Wallin, N. L. (2001). "An Introduction to Evolutionary Musicology”. The Origins of Music. edited by Nils L. Wallin, Björn Merker and Steven Brown. Cambridge: MIT Press. pp. 3-24.

Clayton, M. Sager, R. Will, U. (2005). "In time with the music : the concept of entrainment and its signicance for ethnomusicology.", European meetings in ethnomusicology., 11 (ESEM Counterpoint 1) . pp. 1-82.

Cross, I. (2001). “The Origins of Music”. Book Review. Music Reception. 18(4):513-521.

Fitch, W. T. (2006). “The biology and evolution of music: A comparative perspective”. Cognition. 100: 173215. (2015). "Four principles of bio-musicology". Phil. Trans. R. Soc. B 370: 20140091.

Graham, R. (2015). "Noisy Slience, and Silent Noises". Journal of Biomusical Engineering. 3(1): 108.

Huron, D. (1999). "Lecture 2. An Instinct for Music: Is Music an Evolutionary Adaptation?”. The 1999 Ernest Bloch Lectures. http://csml.som.ohio-state.edu/Music22o/Bloch.lectures/2.Origins.html Accessed Date: 27.12.2016.

Levitin, D. J. (2003). "Precis to an integrated Absolute pitch: Review". Bulletin of Psychology and the Arts. 4(1):17-19.

Morgan, J. E. (2014). "Bird Song". In Music in the Social \& Behavioral Sciences Vol 1. Sage Publications. pp. 138-140.

Nettl, B. (2001). "An Ethnomusicologist Contemplates Universals in Musical Sound and Musical Culture". The Origins of Music. edited by Nils L. Wallin, Björn Merker and Steven Brown. Cambridge: MIT Press. pp. 463-472.

. (2015). “Is Music the Universal Language of Mankind?”. The Study of Ethnomusicology: ThirtyThree Discussions. Urbana: University of Illinois Press. pp.31-46.

Peretz, I. (2006). “The nature of music from a biological perspective”. Cognition. 100:1-32.

Ravignani, A., Gingras, B. (2013). "EvoMus: The evolution of music and language in a comparative perspective”. The 1oth International Conference on the Evolution of Language. 14-17 April 2013.

Rousseau, J. J. (1781/1998). Essay on the Origin of Languages and Writings Related to Music. Trans. John. T. Scott. Hanover: University Press of New England.

Savage, P. E. Brown, S. (2013). “Toward a New Comparative Musicology”. Analytical Approaches to World Music. 2(2): 148-197.

Secora, J. P. G. (2014). "Evolution”. In Music in the Social E Behavioral Sciences Vol 1. Sage Publications. pp. 428-431.

Stumpf, C. (1911/2012). The Origins of Music. Trans. David Trippett. Oxford: Oxford University Press.

Wallin, N. L. (1991). Biomusicology: Neurophysiological, Neuropsychological, and Evolutionary Perspectives on the Origins and Purposes of Music. Stuyvesant,NY: Pendragon Press.

Wallascheck, R. (1893). Primitive Music: An Inquiry Into The Origin and Development of Music, Songs, Instruments, Dances, and Pantomimes of Savage Races. London: Cambridge University Press. 